\title{
Design and application of a flow cell for carbon-film based electrochemical enzyme biosensors
}

\author{
Madalina M. Barsan ${ }^{\mathrm{a}}$, Janja Klinčar ${ }^{\mathrm{b}, \mathrm{c}}$, Martin Batič ${ }^{\mathrm{b}}$, Christopher M.A. Brett ${ }^{\mathrm{a}, *}$ \\ a Departamento de Química, Universidade de Coimbra, 3004-535 Coimbra, Portugal \\ ${ }^{\mathrm{b}}$ Food Science and Technology Department, Biotechnical Faculty, University of Ljubljana, Jamnikarjeva 101, 1000 Ljubljana, Slovenia \\ ${ }^{\mathrm{c}}$ Research Institute for Viticulture and Enology of the Ministry of Agriculture and Rural Development, Urihegy 5/A, 6001 Kecskemét, Hungary
}

Received 25 May 2006; received in revised form 4 August 2006; accepted 21 August 2006

Available online 27 September 2006

\begin{abstract}
A flow cell has been designed for use with an electrochemical enzyme biosensor, based on low-cost carbon-film electrodes. Three types of mediators were used: cobalt and copper hexacyanoferrates and poly(neutral red) (PNR), covered with glucose oxidase (GOx) immobilised by cross-linking with glutaraldehyde in the presence of bovine serum albumin or inside a oxysilane sol-gel network. Mixtures of sol-gel precursors were made from 3-aminopropyl-triethoxysilane (APTOS) together with methyltrimethoxysilane (MTMOS), methyltriethoxysilane (MTEOS), tetraethyloxysilane (TEOS) or 3-glycidoxypropyl-trimethoxysilane (GOPMOS), and the best chosen for encapsulation. Optimisation in batch mode, using amperometric detection at fixed potential, showed the PNR-GOx modified carbon-film electrodes to be best for flow analysis for both glutaraldehyde and sol-gel enzyme immobilisation. Both types of enzyme electrode were tested under flow conditions and the reproducibility and stability of the biosensors were evaluated. The biosensors were used for fermentation monitoring of glucose in grape must and interference studies were also performed.
\end{abstract}

(C) 2006 Elsevier B.V. All rights reserved.

Keywords: Flow cell; Electrochemical enzyme biosensor; Enzyme immobilisation; Sol-gel; Glucose determination; Grape must

\section{Introduction}

Biosensors have found extensive application in different fields such as medicine, food quality and safety control and environment pollution monitoring. The selectivity of the biosensor for the target analyte is mainly determined by the biorecognition element, while the selectivity of the biosensor is greatly influenced by the transducer [1]. Very often the biorecognition elements are enzymes [2] and a good functioning of an electrochemical enzyme biosensor requires a redox mediator, which shuttles electrons between the recognition element and the transducer and reduces interferences since lower applied potentials can be employed.

More than $90 \%$ of commercially available enzyme based biosensors and analytical kits contain oxidase enzymes, and the hydrogen peroxide produced is monitored. When metal hexacyanoferrates, such as copper hexacyanoferrate (CuHCF) or

\footnotetext{
* Corresponding author. Tel.: +351 239 835295; fax: +351 239835295 .

E-mail address: brett@ci.uc.pt (C.M.A. Brett).
}

cobalt hexacyanoferrate (CoHCF), are deposited onto the electrode, they can react electrocatalytically with hydrogen peroxide [3]. Since the electrocatalytic process proceeds at a low applied potential $(\sim 0 \mathrm{~V}$ versus $\mathrm{SCE})$, it is possible to eliminate many of the reactions of interfering species. Such redox mediatormodified electrodes are, therefore, currently being investigated to develop sensors with a suitable catalytic surface for the amperometric detection of hydrogen peroxide, at low potentials, produced by an oxidase [4], such as on carbon-film electrode substrates [5].

The phenazine neutral red (NR) was found to be a convenient artificial enzyme substrate and as a redox mediator for electrochemical investigations of biological redox systems [6]. It has a much lower redox potential than analogous phenothiazine and phenoxazines, due to the second heteroatom which is nitrogen instead of a divalent oxygen or sulphur [6] and has a formal potential at $\mathrm{pH} 7$ of $-0.325 \mathrm{~V}$ versus SHE. The chemical structure of NR, with an amino functionality located on the heteroaromatic phenazine ring, makes it amenable to electropolymerisation. The monomer can be polymerised from neutral aqueous solutions producing stable redox-active layers [7]. 
Immobilisation of enzyme may lead to changes in enzyme structure, stability and specificity, differing from that of the enzyme in homogeneous solution. Therefore, great interest is devoted to find an immobilisation matrix, which can retain its specific biological function. Glutaraldehyde has usually been used as a protein cross-linking agent in biosensor fabrication using carbon-film electrodes [8-13]. Biosensors for glucose determination have been reported using ferrocene [9], CoHCF [10], methyl viologen [11] and PNR [12] as redox mediators, and multienzyme sensors have been used for analysis of various foodstuffs [13]. It is a bifunctional cross-linking agent which reacts with lysine residues on the exterior of the proteins. Addition of bovine serum albumin accelerates the cross-linking process, because of the 35-40 lysine groups present in its structure.

An alternative immobilisation strategy is provided by sol-gel networks. In recent years sol-gel chemistry has paved a versatile path for the immobilisation of biomolecules with a good stability and good activity retention. Enzymes such as horseradish peroxidase (HRP), glucose oxidase (GOx) and acetylcholinesterase (AChE) have been successfully immobilised into oxysilane sol-gel matrices and employed in sensing applications, e.g. [14-17]. The sol-gel reactions proceed by hydrolysis of an alkoxide precursor under acid or basic conditions and condensation of the hydroxylated monomers to form a porous siloxane polymer gel $[18,19]$. Enzyme encapsulation in sol-gel rather than in other matrices can improve some properties such as operational stability and activity compared to cross-linking with glutaraldehyde, and a longer linear range [14,20-22]. Sol-gel biosensors using PNR and $\mathrm{CuHCF}$ as mediators were characterized by cyclic voltammetry, electrochemical impedance spectroscopy and atomic force microscopy [15].

The objective of this work was to develop an electrochemical enzyme biosensor, based on low-cost carbon-film resistor electrodes [23-25], for use in flow analysis. The redox mediators cobalt and copper hexacyanoferrates and poly(neutral red) were tested together with enzyme immobilisation by cross-linking with glutaraldehyde in the presence of bovine serum albumin or by a novel sol-gel GOx encapsulated biosensor with PNR mediator using a combination of oxysilane sol-gel precursors. After optimisation in batch experiments, the best electrodes with PNR mediator were tested in a specially designed flow cell and used to analyse samples of wines. Reproducibility, stability and storage were also evaluated.

\section{Experimental}

\subsection{Reagents}

Glucose oxidase (GOx, EC 1.1.3.4, from Aspergillus niger, 24 units $/ \mathrm{mg}$ ) and phenol were obtained from Fluka, Switzerland, $\alpha$-D(+)-glucose, glutaraldehyde (GA) $25 \%(\mathrm{v} / \mathrm{v})$, bovine serum albumin (BSA), were from Sigma, Germany, D(+) fructose, $\mathrm{L}(-)$ ascorbic acid from Sigma Chemical Co., St. Louis, USA, citric acid, potassium hexacyanoferrate(III) and copper(II) chloride dihydrate were purchased from Merck, Germany. Nafion 5\% $(\mathrm{v} / \mathrm{v})$ in ethanol and neutral red (65\% dye content) were from
Sigma-Aldrich, Germany and tartaric acid from PAHI, Lisbon, Portugal.

For sol-gel enzyme encapsulation, five different oxysilanes were tested in mixtures: 3-aminopropyl-triethoxysilane (APTOS) and tetraethyloxysilane (TEOS) from Fluka, Switzerland, and 3-glycidoxypropyl-trimethoxysilane (GOPMOS), methyltriethyloxysilane (MTEOS) and methyltrimethyloxysilane (MTMOS), all from Aldrich, Germany.

For electrochemical experiments, the supporting electrolyte was sodium phosphate buffer saline (NaPBS) ( $0.1 \mathrm{M}$ phosphate buffer $+0.05 \mathrm{M} \mathrm{NaCl}, \mathrm{pH} 7.0$ ), prepared from sodium dihydrogenphosphate, di-sodium hydrogenphosphate and sodium chloride (Riedel-de Haën). Polymerisation of neutral red was carried out in an electrolyte composed of $0.025 \mathrm{M}$ potassium phosphate buffer solution and $0.1 \mathrm{M} \mathrm{KNO}_{3}(\mathrm{pH} 6)$.

A stock solution of $1.0 \mathrm{M}$ glucose was prepared in supporting electrolyte at least 1 day before use, to permit equilibration of $\alpha$ and $\beta$ anomers of D-glucose; it was kept in the refrigerator and used within 1 week.

Millipore Milli-Q nanopure water (resistivity $>18 \mathrm{M} \Omega \mathrm{cm}$ ) was used for preparation of all solutions. Experiments were performed at room temperature $\left(25 \pm 1^{\circ} \mathrm{C}\right)$.

\subsection{Apparatus}

For batch experiments, a three-electrode electrochemical cell of volume $10 \mathrm{~cm}^{3}$ was used, containing the enzyme modified carbon-film resistor as working electrode, a platinum foil counter electrode and a saturated calomel electrode (SCE) as reference.

A flow cell was specially designed to accommodate the cylindrical carbon-film resistor electrode-based biosensor as working electrode, with a miniature $\mathrm{Ag} / \mathrm{AgCl}(3 \mathrm{M} \mathrm{KCl})$ electrode as reference upstream and a stainless steel tube downstream in the cell exit as counter electrode. After flow rate optimisation in order to achieve the best compromise between sensitivity and consumption of carrier electrolyte, under the optimised conditions a constant flow rate of $13.9 \mu \mathrm{s} \mathrm{s}^{-1}$ was employed, using a peristaltic pump (Pharmacia, Fine Chemicals, Model P-3) connected to a $1-\mathrm{m}$ length of $1 \mathrm{~mm}$ internal diameter Teflon tubing to damp flow oscillations.

All electrochemical measurements were performed using a computer-controlled $\mu$-Autolab Type II potentiostat-galvanostat running with GPES (General Purpose Electrochemical System) for Windows Version 4.9, software (EcoChemie, Utrecht, The Netherlands).

The $\mathrm{pH}$-measurements were carried out with a CRISON 2001 micro $\mathrm{pH}$-meter at room temperature.

HPLC measurements for glucose in grape must were performed using a K-120 pump with an Aminex HPX-87H $(369 \mathrm{~mm} \times 7.8 \mathrm{~mm})$ column containing a sulphonated divinyl benzene-styrene copolymer as support, with detection by differential refractometer (Knauer, Germany). The column was operated at $36^{\circ} \mathrm{C}$ and eluted with $5 \mathrm{mM}$ sulphuric acid (Carlo Erba, Italy) at flow rate $0.6 \mathrm{ml} \mathrm{min}^{-1}$. Peak areas were integrated with Knauer Eurochrome 2000 software and interface box. For sample analysis the external standard method was used. Before analysis, samples were filtered through Chromafil ${ }^{\circledR}$ 
membrane filters (Macherey-Nagel, Germany) with $0.2 \mu \mathrm{m}$ pore size. A constant volume of $20 \mu \mathrm{l}$ sample or standard solution was injected via a $20 \mu \mathrm{l}$ sample loop using an injection valve from NiBest, CA, USA.

\subsection{Electrode and mediator film preparation}

Electrodes were made from carbon-film electrical resistors $(2 \Omega$ resistance) of length $6 \mathrm{~mm}$ and diameter $1.5 \mathrm{~mm}$, as described elsewhere [23]. The exposed geometric area was $\sim 0.20 \mathrm{~cm}^{2}$. Before use, the electrodes were electrochemically pre-treated by cycling the potential between 0.0 and $+1.0 \mathrm{~V}$ versus $\mathrm{Ag} / \mathrm{AgCl}$ in order to decrease the background currents and to increase the potential window. In the case of hexacyanoferrate deposition, the electrolyte was $0.05 \mathrm{M} \mathrm{KCl}$ and in the case of PNR deposition, $0.025 \mathrm{M}$ potassium phosphate buffer solution, pH 5.5 was used.

Films of cobalt(II)-hexacyanoferrate (CoHCF) were electrochemically deposited. This was accomplished by cycling the potential 15 times between 0.0 and $0.9 \mathrm{~V}$ versus SCE at a scan rate of $50 \mathrm{mV} \mathrm{s}^{-1}$, in a freshly prepared solution containing: $0.5 \mathrm{mM} \mathrm{CoCl}_{2} \cdot 6 \mathrm{H}_{2} \mathrm{O}, 0.25 \mathrm{mM} \mathrm{K}_{3} \mathrm{Fe}(\mathrm{CN})_{6}, 0.05 \mathrm{M} \mathrm{NaCl}$ at $\mathrm{pH}$ 3.0 ( $\mathrm{pH}$ adjusted with $\mathrm{HCl}$ ). Subsequently, the $\mathrm{CoHCF}$ film electrodes were stabilised for $1 \mathrm{~h}$ in $0.05 \mathrm{M} \mathrm{NaCl}, \mathrm{pH} 3.0$. They were then left to dry at room temperature $[5,10]$.

Copper(II)-hexacyanoferrate (CuHCF) was deposited in three different ways: by potential cycling between 0.25 and $+0.9 \mathrm{~V}$ versus $\mathrm{SCE}$ for 25 cycles at scan rate $50 \mathrm{mV} \mathrm{s}^{-1}$, by galvanostatic deposition applying a constant current $\left(100 \mu \mathrm{A} \mathrm{cm}^{-2}\right)$ for $300 \mathrm{~s}$ and by direct adsorption, immersing the carbon-film electrode substrate in the deposition solution. Solutions contained $10 \mathrm{mM} \mathrm{CuCl} 2 \cdot 2 \mathrm{H}_{2} \mathrm{O}, 10 \mathrm{mM} \mathrm{K} 3 \mathrm{Fe}(\mathrm{CN})_{6}$ and $100 \mathrm{mM} \mathrm{KCl}$ for all three types of deposition. The solutions were freshly prepared before used and adjusted to $\mathrm{pH} 3.0$ with $\mathrm{HCl}$ [5]. After film formation, the electrodes were dried in a hotair stream (3-4 min) and left for $24 \mathrm{~h}$ in air, at room temperature, to stabilise.

Unfortunately, the structure of the CuHCF mediator film did not lead to good adhesion between the mediator and the enzyme layer. It is also believed that copper ions interact with enzyme molecules leading to a decrease of its biological activity. To avoid this problem, a different strategy was adopted in which mediator powder was added to the enzyme solution and placed on the top of the carbon-film electrode substrate (see below).

The preparation of poly(neutral red) films was carried out by cyclic voltammetry from a solution containing $1 \mathrm{mM}$ neutral red in $0.025 \mathrm{M} \mathrm{KPB}+0.1 \mathrm{M} \mathrm{KNO}_{3}, \mathrm{pH} 6.0$. The potential was cycled from -1.0 to $1.0 \mathrm{~V}$ versus $\mathrm{Ag} / \mathrm{AgCl}$ at a scan rate $50 \mathrm{mV} \mathrm{s}^{-1}$ for 15 cycles [12].

Glucose oxidase was immobilised using two methods. In the first, glutaraldehyde (GA) cross-linking, a volume of $35 \mu \mathrm{l}$ of an enzyme mixture contain $25 \mu \mathrm{l}$ enzyme solution (100 mg glucose $+40 \mathrm{mg}$ BSA per ml $0.1 \mathrm{M} \mathrm{NaPBS}, \mathrm{pH} 7)$ and $10 \mu \mathrm{l} \mathrm{GA}$ $(2.5 \%, \mathrm{v} / \mathrm{v}$ diluted in water) was prepared. Of this mixture, $10 \mu \mathrm{l}$ was dropped onto the electrode surface and left to dry at room temperature during $1 \mathrm{~h}[10]$. To prepare the $\mathrm{CuHCF} / \mathrm{GOx}$ modified biosensors the enzyme mixture contained: $10 \%(w) \mathrm{CuHCF}$

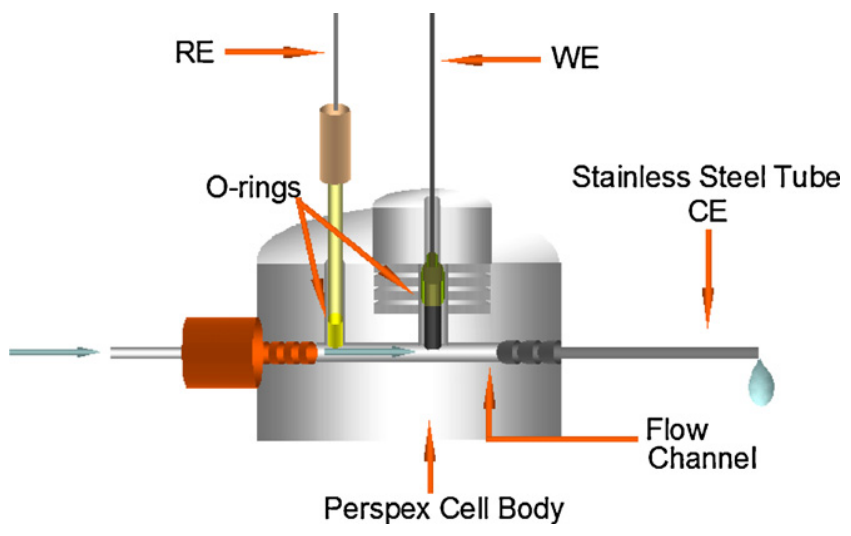

Fig. 1. Cross-section of flow-through cell, diameter $5 \mathrm{~cm}$, height $2.5 \mathrm{~cm}$; flow channel $1.5 \mathrm{~mm}$ diameter. $\mathrm{RE}, \mathrm{Ag} / \mathrm{AgCl}$ reference electrode; WE, carbon-film working electrode; CE, counter electrode.

powder, $25 \mu$ l enzyme solution and $9 \mu \mathrm{l} \mathrm{GA} 2.5 \%$; the enzyme solution was the same as for the preparation of PNR/GOx and $\mathrm{CoHCF} / \mathrm{GOx}$ biosensors.

For the second method, sol-gel enzyme encapsulation, sol-gel solutions were prepared using mixtures of APTOS and one other sol-gel precursor in NaPBS solution, $\mathrm{pH}$ 7.0. Two sol-gel mixture were found to be most appropriate for enzyme encapsulation, which contained APTOS:GOPMOS and APTOS:MTMOS, both in the ratio 1:3. About $15 \mu$ l of sol-gel solution was mixed with $15 \mu$ l of enzyme solution ( $100 \mathrm{mg}$ glucose $+40 \mathrm{mg}$ BSA per ml of $0.1 \mathrm{M} \mathrm{NaPBS}, \mathrm{pH} 7$ ) and $5 \mu \mathrm{l}$ of glycerol to improve homogeneity.

The enzyme layer of all biosensors prepared was coated with $5 \mu \mathrm{l}$ of Nafion (5\% solution) to improve the physical robustness of the sensor and to act as a barrier against interferences.

\section{Results and discussion}

The principal objective of this work is to develop an efficient and reproducible analytical flow cell method for continuous monitoring, so that it is particularly important that the biosensor assembly be robust and the enzyme activity remain unchanged over time. For this reason, a comparison between the three mediators and the two enzyme immobilisation techniques was carried out in batch mode before application in the flow cell and testing with natural samples.

\subsection{Flow cell}

The specially designed cylindrical flow cell was constructed from Perspex and is shown in Fig. 1 in cross-section. Samples are introduced $10 \mathrm{~cm}$ before the cell inlet. The working electrode is centred in the cell and located between the upstream reference electrode and the downstream counter electrode; the inlet tubing is of $1 \mathrm{~mm}$ internal diameter and the flow channel is $1.5 \mathrm{~mm}$ in diameter. Various flow rates were tested by amperometry using the assembled biosensors (see below). The results of these studies were that the best compromise between biosensor sensitivity and carrier solution consumption was the pump setting corresponding to $13.9 \mu \mathrm{s} \mathrm{s}^{-1}$. At a lower flow rate of $6.9 \mu \mathrm{ls}^{-1}$ the 
sensitivity decreased by $37 \%$. A higher flow rate increases the mass transfer of analyte to the electrode surface so an increase in response current should be obtained, but above $13.9 \mu 1 \mathrm{~s}^{-1}$, no significant increase in sensitivity was observed, presumably due to kinetic limitations.

\subsection{Mediator deposition}

The modification of carbon-film electrodes with hexacyanoferrates has previously been described in detail [5]. Optimised deposition of $\mathrm{CoHCF}$ by potential cycling between 0.0 and 0.9 $\mathrm{V}$ versus SCE, as in Ref. [10], is shown in Fig. 2a. The modified electrodes were kept in $0.05 \mathrm{M} \mathrm{NaCl}$ supporting electrolyte, in this way yielding a stable CV response. As described in Section 2, electrodes modified by $\mathrm{CuHCF}$ films were found not to be as stable as $\mathrm{CoHCF}$ when covered with the sol-gel enzyme layer.
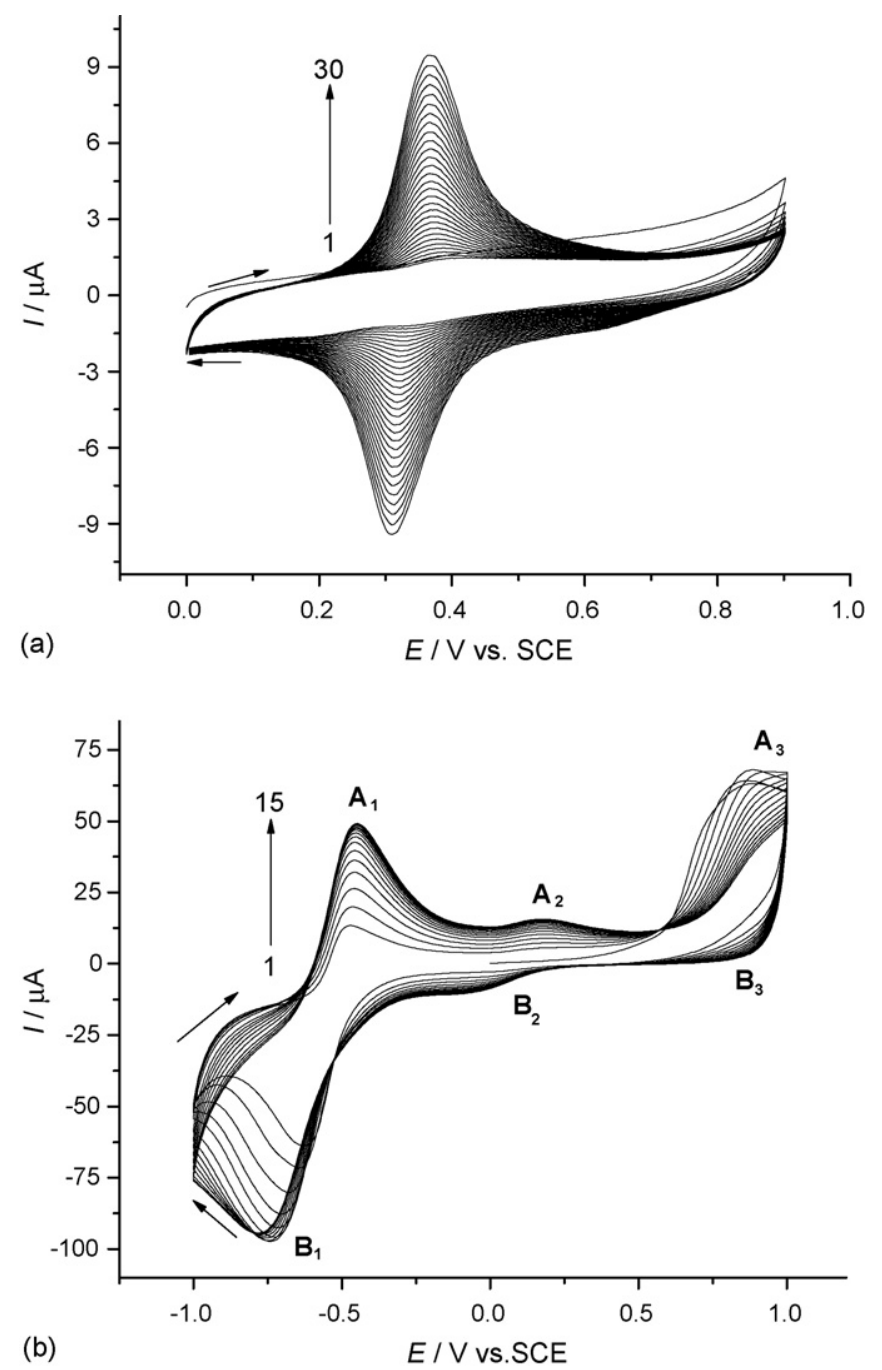

Fig. 2. Cyclic voltammograms showing growth of mediator films on carbonfilm electrodes by potential cycling. (a) $\mathrm{CoHCF}$ from a solution containing $0.5 \mathrm{mM} \mathrm{CoCl}_{2} \cdot 6 \mathrm{H}_{2} \mathrm{O}, 0.25 \mathrm{mM} \mathrm{K}_{3} \mathrm{Fe}(\mathrm{CN})_{6}, 0.05 \mathrm{M} \mathrm{NaCl}$ at $\mathrm{pH} 3$; scan rate $=50 \mathrm{mV} \mathrm{s}^{-1}$; 30 cycles; (b) poly(neutral red) from a solution containing $1 \mathrm{mM}$ neutral red, $0.025 \mathrm{M}$ potassium phosphate buffer $\mathrm{pH} 6.0,0.1 \mathrm{KNO}_{3}$; initial scan in positive direction from $0 \mathrm{~V}$; scan rate $50 \mathrm{mV} \mathrm{s}^{-1} ; 15$ cycles.
Preparation of PNR films was done as in Ref. [12] by potential cycling from -1.0 to $1.0 \mathrm{~V}$ versus SCE for 15 cycles, see Fig. 2b. The $0.1 \mathrm{M} \mathrm{KNO}_{3}$ electrolyte was chosen because of the observed catalytic effect of $\mathrm{NO}_{3}{ }^{-}$anions on neutral red polymerisation. After initial formation of a radical cation, the electropolymerisation is fast in the first 10 cycles after which the current increased less. The peak system $\mathrm{B}_{1}, \mathrm{~A}_{1}$ corresponds to the reduction and reoxidation of the polymer, in the presence of aqueous medium or hydrogen ions, respectively [26-30], in the same potential range as for reduction and oxidation of the neutral red monomer.

\subsection{Evaluation of glucose biosensors in batch mode}

\subsubsection{Immobilisation of GOx by cross-linking with $G A$}

The biosensors with a film of one of the three different mediators covered by GOx immobilised by cross-linking with GA were tested in a batch cell in order to compare their properties. The applied potential was $0.0 \mathrm{~V}$ for the CoHCF-GOx biosensor, $+0.05 \mathrm{~V}$ for the CuHCF-GOx biosensor and $-0.35 \mathrm{~V}$ versus SCE for the PNR-GOx biosensor, optimum values found in previous work $[5,10,15]$. After stabilisation of the current baseline, amperometric measurements were performed, by injection of glucose into $0.1 \mathrm{M} \mathrm{NaPBS}$ solution containing the biosensor, under continuous stirring. The results obtained are shown in Table 1 .

The PNR-GOx biosensor had the best sensitivity of $820 \mathrm{nA} \mathrm{mM}^{-1}$ compared with 38.5 for CuHCF-GOx and $9.6 \mathrm{nA} \mathrm{mM}^{-1}$ for CuHCF-GOx sensors, as well as the lowest detection limit $(46 \mu \mathrm{M})$ and a linear range up to $1.2 \mathrm{mM}$. PNRGOx was therefore chosen for use in the flow cell and PNR was also chosen as the redox mediator for testing the biosensors with enzyme encapsulated in a sol-gel matrix.

\subsubsection{Sol-gel immobilisation of GOx}

3.3.2.1. Optimisation of sol-gel composition and preparation. Different sol-gel mixtures were tested and analysed, see Table 2, all containing APTOS as one of the sol-gel components. Solutions were prepared by first mixing APTOS with $0.1 \mathrm{M} \mathrm{NaPBS}$ $\mathrm{pH} 7.0$ and then adding the second sol-gel precursor in different volume ratios. Initially, the second monomer was added after mixing APTOS with NaPBS solution, but in all cases precipitation occurred. In order to avoid this problem, prior to adding the second monomer, the APTOS-NaPBS solution was neutralized with 1:1 $\mathrm{HCl}$. The solutions were then intensively stirred and sonicated during $10-15 \mathrm{~min}$ and heated in a hot-air stream at $\sim 70{ }^{\circ} \mathrm{C}$ for different times as necessary.

Table 1

Analytical data obtained from glucose calibration curves registered at CoHCF-, CuHCF- and PNR-GOx (GA) biosensors in batch analysis

\begin{tabular}{lccl}
\hline Mediator & Sensitivity $\left(\mathrm{nA} \mathrm{mM}^{-1}\right)$ & Detection limit $(\mu \mathrm{M})$ & $K_{\mathrm{M}}(\mathrm{mM})$ \\
\hline CoHCF & 9.6 & 140 & 4.2 \\
CuHCF & 38.5 & 130 & 5.0 \\
PNR & 820 & 54 & 6.0 \\
\hline
\end{tabular}


Table 2

Sol-gel mixture preparation from different precursors

\begin{tabular}{|c|c|c|c|}
\hline Sol-gel composition $(\mu \mathrm{l})$ & Heating time $(\mathrm{min})$ & Gelation time (h) & Other observations \\
\hline APTOS:MTMOS:PBS:HCl 146.6:74.4:580:15 & - & Prompt & $\begin{array}{l}\text { Immediately after precursor mixing, a white } \\
\text { precipitate is formed }\end{array}$ \\
\hline APTOS:MTMOS:PBS:HCl 55:165:580:3 & 5 & 3 & $\begin{array}{l}\text { APTOS neutralized prior to MTMOS addition; } \\
\text { enzyme goes into solution }\end{array}$ \\
\hline APTOS:MTMOS:PBS:HCl 146.6:74.4:580:15 & 8 & 15 & APTOS neutralized prior to MTMOS addition \\
\hline APTOS:TEOS:PBS:HCl 146.6:74.4:580:15 & - & 24 & $\begin{array}{l}\text { Sol-gel dissolves from the electrode into } \\
\text { solution }\end{array}$ \\
\hline APTOS:MTEOS:PBS:HCl 74.4:146.6:580:10 & 5 & Prompt & Gelation during heating \\
\hline APTOS:MTEOS:PBS:HCl 110:110:580:20 & 15 & Prompt & Gelation during heating \\
\hline APTOS:GOPMOS:PBS:HCl 74.4:146.6:580:10 & 40 & 24 & APTOS neutralized prior to GOPMOS addition \\
\hline APTOS:GOPMOS:PBS:HCl 110:110:580:20 & 15 & Prompt & Gelation during heating \\
\hline APTOS:GOPMOS:PBS:HCl 55:165:580:20 & - & 8 & APTOS neutralized prior to GOPMOS addition \\
\hline
\end{tabular}

Table 3

Analytical data obtained from glucose calibration curves at PNR-GOx (sol-gel) biosensors in batch analysis

\begin{tabular}{llll}
\hline Sol-gel mixture & Sensitivity $\left(\mu \mathrm{AmM}^{-1}\right)$ & Correlation coefficient $\left(R^{2}\right)$ & Limit of detection $(\mu \mathrm{M})$ \\
\hline APTOS:GOPMOS:PBS:HCl 55:165:580:20 & 0.70 & 0.999 & 20 \\
APTOS:MTMOS:PBS:HCl 55:165:580:3 & 0.39 & 0.998 & 73 \\
\hline
\end{tabular}

It was not possible to find a good method to mix TEOS or MTEOS with APTOS. In the first case, the mixture was not homogeneous and in the second, prompt gelation occurred after a few minutes of heating, which was necessary to remove as much alcohol as possible, since it is prejudicial to the enzyme.

Two mixtures were found to be appropriate for enzyme encapsulation, using APTOS:GOPMOS 1:3 and APTOS:MTMOS $1: 3$, as mentioned in Section 2 and following the protocol described in Table 2.

3.3.2.2. Comparison of sol-gel precursor mixtures with the PNR-GOx biosensor. Using optimised mixtures of sol-gel precursors, PNR-GOx (sol-gel) biosensors were constructed and applied in batch analysis for glucose determination, performing amperometric measurements at fixed potential. Analytical data calculated from the calibration curves are shown in Table 3. A higher sensitivity was achieved with biosensors using the mixture APTOS:GOPMOS 1:3, also having a lower detection limit and a longer linear range, up to $1.1 \mathrm{mM}$. The relative standard deviation was found to be $\sim 3.6 \%(n=3)$ in the case of APTOS:GOPMOS 1:3 and 7.6\% $(n=3)$ for APTOS:MTMOS $1: 3$.

\subsection{Flow analysis}

\subsubsection{Voltammetric behaviour of PNR-GOx biosensors}

Since PNR-GOx biosensors had been identified as the ones with the most favourable response characteristics in batch analysis, they were evaluated for analysis in the flow cell using enzyme immobilisation by cross-linking with glutaraldehyde (BSA) or by sol-gel entrapment.

Cyclic voltammograms were recorded in the flow cell at these biosensors in $0.1 \mathrm{M}$ NaPBS pH 7.0 electrolyte using a constant flow rate of $13.9 \mu \mathrm{ls}^{-1}$, without and with the enzyme layer, Fig. 3. As can be seen, deposition of enzyme using the crosslinking method led to a decrease of the oxidation peak current by $44 \%$, while in the case of sol-gel enzyme entrapment the oxidation peak current decreased by $74 \%$. Nevertheless, PNR exhibits the same reversible behaviour after immobilisation of enzyme using either of the two techniques, with the same peak separation of $0.27 \mathrm{~V}$.

\subsubsection{Glucose determination at PNR-GOx biosensors}

The two types of biosensor were applied to glucose determination in the flow cell at the optimised flow rate of $13.9 \mu \mathrm{s} \mathrm{s}^{-1}$ (see Section 3.1). The carrier electrolyte solution was $0.1 \mathrm{M}$

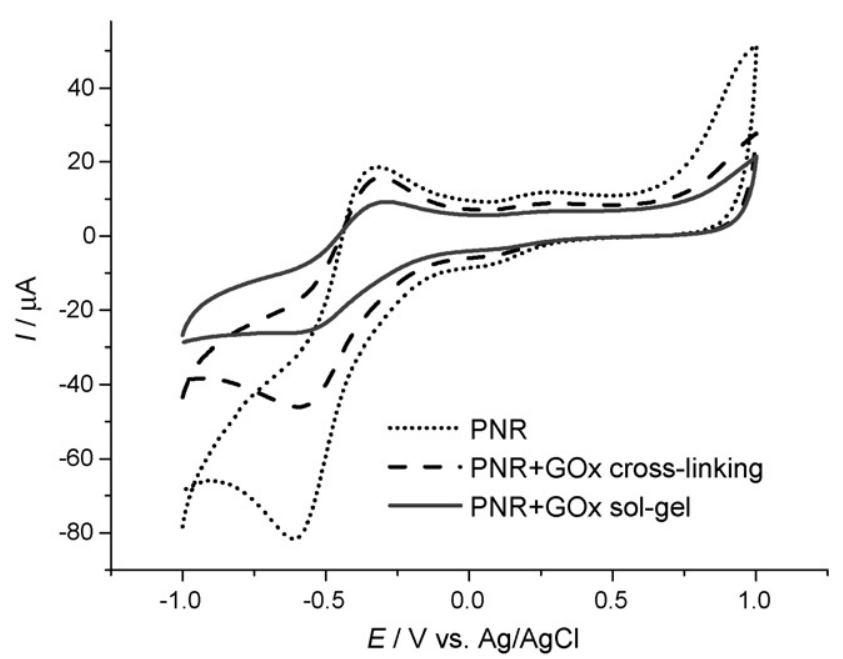

Fig. 3. Cyclic voltammograms in flow cell at PNR modified carbon-film electrodes and at PNR-GOx biosensors (GA, sol-gel) in 0.1 NaPBS, pH 7.0; scan rate $=50 \mathrm{mV} \mathrm{s}^{-1}$. 


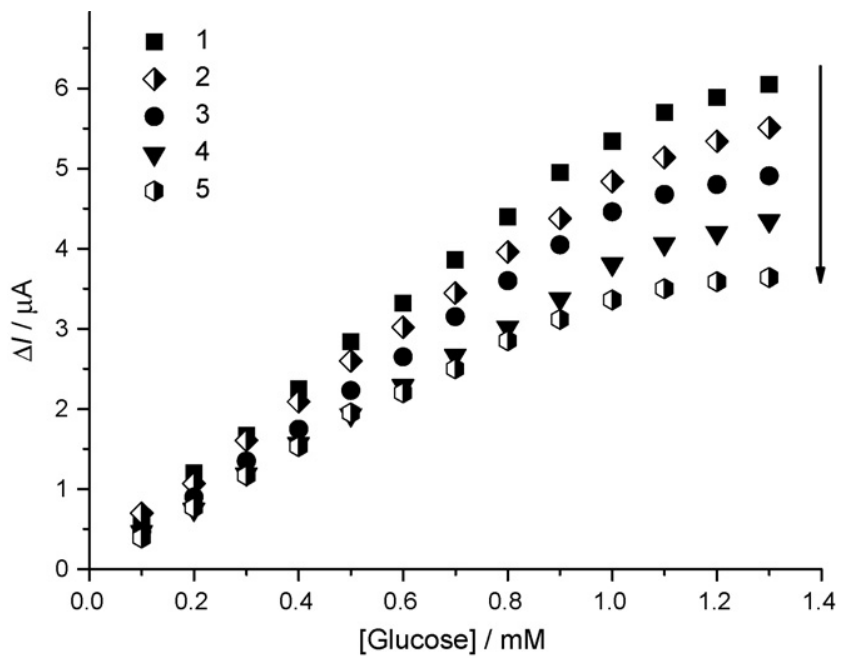

Fig. 4. Calibration curves for glucose at PNR-GOx (GA) biosensor, at $-0.35 \mathrm{~V}$ vs. $\mathrm{Ag} / \mathrm{AgCl}: 1$, initially; 2, after 7 days; 3 , after 14 days; 4, after 21 days; 5, after 30 days.

NaPBS and glucose-containing solution was injected directly into the carrier stream.

3.4.2.1. PNR-GOx biosensor (GA). Fig. 4 shows calibration curves registered at the PNR-GOx (GA) biosensor. The biosensor response was found to be higher under flow conditions than in stationary solution, as expected, with a sensitivity of $5.34 \mu \mathrm{AmM}^{-1}$, an increase of a factor of 5 , and a detection limit of $35 \mu \mathrm{M}$.

In order to examine the reproducibility of the biosensor, the amperometric response to glucose at three PNR-GOx (GA) modified electrodes was recorded in the same experimental conditions. The biosensors showed a linear range up to $0.9 \mathrm{mM}$ and the corresponding detection limit (signal-to-noise ratio $=3)$ was $36.0 \pm 3.2 \mu \mathrm{M}(n=3)$. The biosensor sensitivity was $5.28 \pm 0.10 \mu \mathrm{AmM}^{-1}$. Thus, the sensors showed a sufficiently good, reproducible behaviour to be used for on-line measurements. Kinetic studies of the immobilised enzyme were also carried out. The Michaelis-Menten constant was calculated from Lineweaver-Burk plots and the value obtained was $5.1 \pm 0.4 \mathrm{mM}(n=3)$.

A good biosensor for flow analysis has to be robust and to show a good long-term stability. In order to check these characteristics, the biosensors were tested during 1 month, see Fig. 5. After 1 week the sensitivity decreases by only $13.1 \%$, continuing to decrease linearly until the end of the month, 30 days, when it reached a value of $3.32 \mu \mathrm{AmM}^{-1}$, corresponding to $62 \%$ of the initial value. At this point in time, the enzyme layer also showed evidence of beginning to crack.

3.4.2.2. PNR-GOx biosensor (sol-gel). The PNR-GOx biosensor with enzyme trapped in sol-gel made from the optimised precursor ratio of APTOS:GOPMOS 1:3 was used for the determination of glucose in the flow cell, at $-0.35 \mathrm{~V}$ versus $\mathrm{Ag} / \mathrm{AgCl}$. As seen in Fig. 5, a lower sensitivity but a longer linear range than in the PNR-GOx (GA) biosensor was obtained. The sensitivity was $0.81 \pm 0.02 \mu \mathrm{A} \mathrm{mM}^{-1}$ and the detection limit $62.0 \mu \mathrm{M}$. The

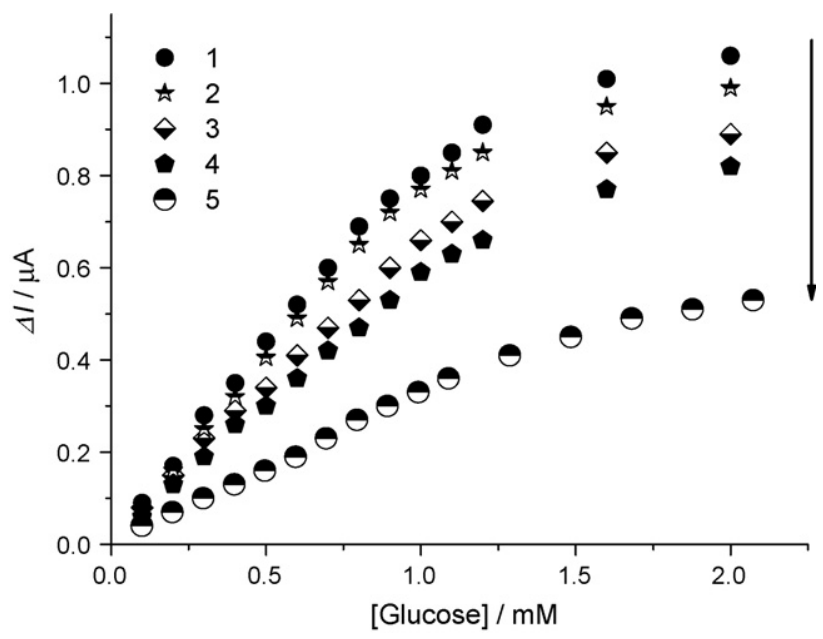

Fig. 5. Calibration curves for glucose at PNR-GOx (sol-gel) biosensor, at $-0.35 \mathrm{~V}$ vs. $\mathrm{Ag} / \mathrm{AgCl}$ : 1, initially; 2, after 4 days; 3, after 14 days; 4, after 35 days; 5 , after 46 days.

calculated Michaelis-Menten constant from Lineweaver-Burk plots was $3.2 \pm 0.8 \mathrm{mM}$.

The biosensor was tested during 46 days, $2-3$ times per week. Some of these calibration curves are plotted in Fig. 5: the sensitivity decreases with time, reaching $63 \%$ of the initial value after 46 days. This decrease is less than at the GAimmobilised enzyme, demonstrating that sol-gel encapsulation of the enzyme leads to a biosensor that is stable over a longer period. Other work cited in the literature regarding the application of a GOx biosensor in flow analysis is not focused on long-term stability evaluation of the electrochemical biosensor. A comparison regarding the sensitivity and the detection limit of the biosensor showed a very good performance of the developed system [31-35]. The $4000 \mathrm{nA} \mathrm{mM}^{-1} \mathrm{~cm}^{-2}$ sensitivity of the sol-gel biosensor developed here is much higher when compared with other sol-gel biosensors developed for flow analysis with a sensitivity of $96 \mathrm{nA} \mathrm{mM}{ }^{-1}$ or $81 \mathrm{nA} \mathrm{mM}^{-1} \mathrm{~cm}^{-2}[31,34]$ or with other biosensor assemblies such as an epoxy-graphiteTTF.TCNQ-GOD biocomposite developed for flow analysis with a sensitivity of $23.5 \mathrm{nA} \mathrm{mM} M^{-1} \mathrm{~cm}^{-2}$ [35].

\subsection{Interference study in the flow cell}

The final aim of this work is to use the flow cell biosensors for monitoring of glucose during fermentation of grape must or in wine. A study of interferences from compounds usually present in wine was therefore performed and the results obtained for the two types of enzyme immobilisation, are presented in Table 4. Fructose, the main sugar present in wine besides glucose, decreases the biosensor response by only $4 \%$ for the PNR-GOx biosensor (GA) and 7\% for the PNR-GOx biosensor (sol-gel). From the acids mainly found in wine, only ascorbic acid interferes with glucose, but only slightly decreases the response to glucose with 20 for the first type of biosensor or $12 \%$ for the second one. The interference from phenol does not need to be taken into account in glucose measurements, since its concentration is small in wine. 
Table 4

Interference of some compounds on the response to glucose at PNR-GOx biosensors

\begin{tabular}{lcc}
\hline Compound & \multicolumn{2}{l}{$\begin{array}{l}\text { Relative response (\%) 2:1 (molar ratio) } \\
\text { interferent compound:glucose }\end{array}$} \\
\cline { 2 - 3 } & PNR-GOx (GA) & PNR-GOx (sol-gel) \\
\hline Fructose & 96 & 93 \\
Acetic acid & 100 & 92 \\
Tartaric acid & 93 & 96 \\
Phenol & 86 & 89 \\
Ascorbic acid & 80 & 88 \\
\hline
\end{tabular}

\subsection{Flow analysis of glucose in natural samples}

The biosensors based on the PNR polymer-film were applied to the amperometric determination of glucose at $-0.35 \mathrm{~V}$ versus $\mathrm{Ag} / \mathrm{AgCl}(3 \mathrm{M} \mathrm{KCl})$. The results obtained in grape must samples, collected at different fermentation times in a winery are represented in Fig. 6. The concentrations for glucose were compared with those obtained using HPLC.

Wine samples were analysed using the standard addition method and also from calibration curves. The samples were diluted 250, 500 and 1000 times in 0.1 M NaPBS.

The recovery of the analytical signal for each of the must samples is $105,106,92,101,98$ and $102 \%$, respectively [36], and the maximum loss in biosensor activity after the sample assay was $4 \%$.

As can be seen in Fig. 6, the glucose concentration in the grape must decreases during the fermentation process, as expected. The fermentation profile for glucose is very similar using the two determination methods. The differences can be explained taking into account that the preservation conditions of the samples were different, and it was not possible to filter the samples immediately after they were removed from the fermentation vat, so that the yeasts could cause further fermentation after sample collection.

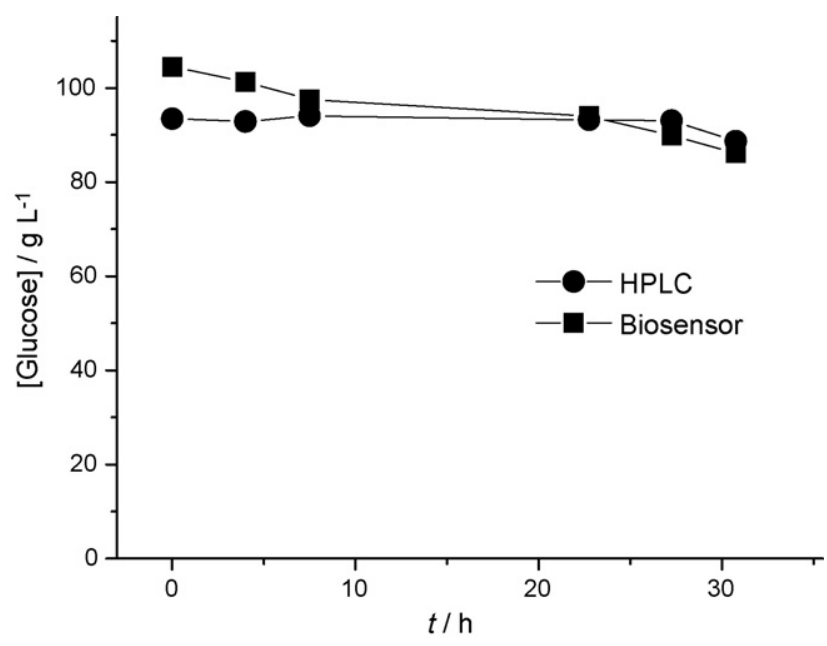

Fig. 6. Glucose determination in grape must during fermentation with PNRGOx (GA) biosensor; comparison with HPLC results.

\section{Conclusions}

A new flow cell, using electrochemical glucose redoxmediated enzyme biosensors, based on low-cost carbon-film resistors, has been designed and evaluated. Of the three types of mediator film tested - $\mathrm{Co}$ (II) hexacyanoferrate, $\mathrm{Cu}$ (II) hexacyanoferrate and poly(neutral red) - PNR was found to lead to the best results. Glucose oxidase enzyme was immobilised by cross-linking with glutaraldehyde or by encapsulation in a sol-gel matrix. Various mixtures of sol-gel precursor were tested, the best being GOPMOS and APTOS in a proportion of 3:1. The biosensors were tested in batch analysis and the stability and reproducibility evaluated. Both biosensors were tested in flow analysis leading to the conclusion that sol-gel encapsulation led to superior sensor characteristics. Biosensors with cross-linked enzyme were used for fermentation monitoring of glucose in three different musts and the obtained glucose values compared with HPLC values. The results show that the developed biosensors can be successfully applied to glucose monitoring in wines and during grape fermentation processes.

\section{Acknowledgements}

Financial support from European Project NOVTECH, HPRN-CT-2002-00186, and from Fundação para a Ciência e Tecnologia (FCT) Portugal, ICEMS (Research Unit 103) is gratefully acknowledged.

\section{References}

[1] J. Castillo, S. Gáspár, S. Leth, M. Niculescu, A. Mortari, I. Bontidean, V. Soukharev, S.A. Dorneanu, A.D. Ryabov, E. Csöregi, Sens. Actuators B: Chem. 102 (2004) 179.

[2] J.-C. Vidal, E. Garcia-Ruiz, J.-R. Castillo, Microchim. Acta 143 (2003) 93.

[3] F.W. Scheller, D. Pfeiffer, F. Schubert, R. Reneberg, D. Kirstein, in: A.P.F. Turner, I. Karube, G.S. Wilson (Eds.), Biosensors: Fundamental and Applications, Oxford University Press, Oxford, 1987.

[4] L. de Mattos, L. Gorton, T. Laurell, A. Malinauskas, A.A. Karyakin, Talanta 52 (2000) 792.

[5] R. Pauliukaite, M. Florescu, C.M.A. Brett, J. Solid State Electrochem. 9 (2005) 354

[6] A.A. Karyakin, E.E. Karyakina, H.L. Schmidt, Electroanalysis 11 (1999) 149.

[7] A.A. Karyakin, O.A. Bobrova, E.E. Karyakina, J. Electroanal. Chem. 399 (1995) 181.

[8] M. Florescu, C.M.A. Brett, Talanta 65 (2005) 306.

[9] M.E. Ghica, C.M.A. Brett, Anal. Lett. 38 (2005) 907.

[10] M. Florescu, C.M.A. Brett, Anal. Lett. 37 (2004) 871.

[11] M.E. Ghica, C.M.A. Brett, Anal. Chim. Acta 532 (2005) 145.

[12] M.E. Ghica, C.M.A. Brett, Electroanalysis 18 (2006) 748.

[13] S. De Luca, M. Florescu, M.E. Ghica, A. Lupu, G. Palleschi, C.M.A. Brett, D. Compagnone, Talanta 68 (2005) 171.

[14] R. Pauliukaite, C.M.A. Brett, Electrochim. Acta 50 (2005) 4973.

[15] R. Pauliukaite, A.-M. Chiorcea-Paquim, A.M. Oliveira Brett, C.M.A. Brett, Electrochim. Acta 52 (2006) 1.

[16] P.C. Pandey, S. Upadhyay, I. Tiwari, V.S. Tripathi, Electroanalysis 11 (1999) 1251.

[17] P.C. Pandey, S. Upadhyay, I. Tiwari, V.S. Tripathi, Sens. Actuators B: Chem. 72 (2001) 224

[18] T. Noguer, D. Szydlowska, J.-L. Marty, M. Trojanowicz, Polish J. Chem. 78 (2004) 1679.

[19] A.C. Pierre, Biocatal. Biotransfor. 22 (2004) 145. 
[20] O. Lev, Z. Wu, S. Bharathi, V. Glezer, A. Modestov, J. Gun, L. Rabinovich, S. Sampath, Chem. Mater. 9 (1997) 2354.

[21] L. Rabinovich, O. Lev, Electroanalysis 13 (2001) 265.

[22] G. Shustak, S. Marx, I. Turyan, D. Mandler, Electroanalysis 15 (2003) 398.

[23] C.M.A. Brett, L. Angnes, H.-D. Liess, Electroanalysis 13 (2001) 765.

[24] O.M.S. Filipe, C.M.A. Brett, Electroanalysis 16 (2004) 994.

[25] C. Gouveia-Caridade, C.M.A. Brett, Electroanalysis 17 (2005) 549.

[26] C. Kuhnhardt, J. Electroanal. Chem. 369 (1994) 71.

[27] P.J. Kulesza, M.A. Malik, S. Zamponi, M. Berretoni, R. Marassi, J. Electroanal. Chem. 397 (1995) 288.

[28] J.M. Bauldreay, M.D. Archer, Anal. Chim. Acta 28 (1983) 1515

[29] T. Selvaraju, R. Ramaraj, Electrochem. Commun. 5 (2003) 667.
[30] D. Benito, J.J. Garcia-Jareño, J. Navarro-Laboulais, F. Vincente, J. Electroanal. Chem. 446 (1998) 47.

[31] V.B. Kandimalla, V.S. Tripathi, H. Ju, Biomaterials 27 (2006) 1167.

[32] E. Maestre, I. Katakis, A. Narváez, E. Domínguez, Biosens. Bioelectron. $21(2005) 774$

[33] C.G. Tsiafoulis, A.B. Flourou, P.N. Trikalitis, T. Bakas, M.I. Prodromidis, Electrochem. Commun. 7 (2005) 781.

[34] C.M.C.M. Couto, A.N. Araújo, M.C.B.S.M. Montenegro, J. Rohwedder, I. Raimundo, C. Pasquini, Talanta 56 (2002) 997.

[35] X. Llopis, A. Merkoçi, M. del Valle, S. Alegret, Sens. Actuators B 107 (2005) 42.

[36] D.T. Burns, K. Danzer, A. Townshend, Pure Appl. Chem. 74 (2002) 2201. 